\title{
HUBUNGAN INDEX MASSA TUBUH DENGAN GRADING PADA KANKER PAYUDARA
}

\section{THE RELATIONSHIP OF BODY MASSA INDEX WITH GRADING ON BREAST CANCER}

\author{
Arif Nurhidayat Prawirohardjo, Widyanti Soewoto, Untung Alifianto \\ Sub Bagian Bedah Onkologi. Bagian Ilmu Bedah. RSUD dr. Moewardi Surakarta \\ Korespondensi: dr. Arif Nurhidayat Prawirohardjo, Sp. B. Email: arifprawirohardjo@gmail.com
}

\begin{abstract}
ABSTRAK
Kanker payudara merupakan kanker paling umum pada wanita di seluruh dunia dan merupakan kanker paling banyak terjadi pada wanita. WHO telah merekomendasikan klasifikasi IMT termasuk derajat underweight atau overweight berhubungan dengan peningkatan risiko beberapa penyakit tidak menular. Differensiasi tingkat keganasan untuk kanker payudara, menggunakan kriteria WHO yaitu system grading Nottingham (juga disebut modifikasi Elston_Ellis dari sistem grading Scarff-Bloom-Richardson). Penelitian ini bertujuan untuk mengetahui hubungan Index Massa Tubuh dengan Grading pada kanker payudara. Penelitian ini merupakan studi observasional analitik dengan desain Cross Sectional untuk mempelajari hubungan Indeks Massa Tubuh dengan Grading kanker payudara. Karaktersitik berdasarkan umur minimum 28 tahun dan usia maksimum 64 tahun, berat badan pasien minimum $40 \mathrm{~kg}$ dan maksimum $75 \mathrm{~kg}$. Tinggi badan pasien minimum $141 \mathrm{~cm}$ dan maksimum $163 \mathrm{~cm}$,skor IMT minimum 17.22 dan maksimum 31.18. Berdasarkan IMT dalam kategori Underwight ada 2 orang (6,7\%), IMT dalam kategori normowight ada 18 orang $(60,0 \%)$, dan pasien dengan IMT dalam kategori overwight ada 10 orang (33.3\%), dengan demikian responden mayoritas dengan hasil pengukuran IMT dalam kategori normowight. Derajat diferensiasi sel dalam kategori Grade I ada 2 orang (6,7\%), derajat diferensiasi sel dalam kategori Grade II ada 8 orang (26,7\%), dan derajat diferensiasi sel dalam kategori Grade III ada 20 orang (66.7\%), dengan demikian responden mayoritas dengan hasil pengukuran derajatdiferensiasiseldalam kategori Grade III. Pasien dengan grading kanker payudara grade 1 dengan IMT underweight ada 1 orang dan normowight ada 1 orang, pada grading kanker payudara grade II yang normoweight ada 7 orang dan overweight ada 1 orang, dan pada grading kanker payudara grade III dengan IMT underweight ada 1 orang normoweight ada 10 orang dan overweight ada 9 orang. IMT overwight lebih berisiko terhadap tingginya grade pada grading kanker payudara, nilai koefisen korelasi sebesar 0,396 dengan nilai $p=0,045(p<0,05)$ yang berarti terdapat hubungan yang signifikan antara Index Masa Tubuh dengan Grading pada kanker payudara.
\end{abstract}

Kata Kunci: Kanker Payudara, Index Masa Tubuh, Differensiasi Histopatologi

\section{ABSTRACT}

Breast cancer is the most common cancer in women worldwide and is the most common cancer in women. WHO has recommended the classification of IMT including underweight or overweight degree related to increased risk of some non-infectious diseases. Differentiation of malignancy stages for breast cancer, using the WHO criteria of Nottingham's grading system (also called Elston_Ellis modification of the Scarff-Bloom-Richardson grading system). This study aims to determine the relationship of Body Mass Index with Grading on breast cancer. This study is an analytic observational study with Cross Sectional design to study the relationship of Body Mass Index with breast cancer Grading. Characteristic based on minimum age 28 years and age maximum 64 years old, patient weight minimum $40 \mathrm{~kg}$ and maximum $75 \mathrm{~kg}$. The patient's minimum height is $141 \mathrm{~cm}$ and maximum $163 \mathrm{~cm}$, minimum IMT score 17.22 and maximum 31.18. Based on IMT in the category of Ederwight there are 2 people (6.7\%), IMT in the category of normowight there are 18 people (60.0\%), and patients with BMT in overwight category there are 10 people (33.3\%), thus majority respondents with measurement results IMT in the normowight category. The degree of cell differentiation in the Grade I category was 2 people (6.7\%), the degree of cell differentiation in the Grade II category was 8 people (26.7\%), and the degree of cell differentiation in Grade III category was 20 (66.7\%), thus the majority of respondents with the result of the measurement of differentiated degrees in the Grade III category. Patients with grade 1 breast cancer grading with underweight IMT there was 1 person and normowight there was 1 person, on grading grade II breast cancer normoweight there were 7 people and overweight there was 1 person, and in grade 3 breast cancer grading with IMW underweight there was 1 
person normoweight exist 10 people and overweight there are 9 people. Overwight BMI is more risk for high grade on breast cancer grading, correlation coefficient value of 0.396 with $p=0,045(p<0,05)$ which means there is significant relation between Body Index with Grading on breast cancer.

Keywords: Breast Cancer, Body Mass Index, Histopathology Differentiation

\section{PENDAHULUAN}

Kanker payudara merupakan kanker paling umum pada wanita di seluruh dunia dan merupakan kanker paling banyak terjadi pada wanita. Kejadian kanker payudara sebanyak 1.677.000 kasus (WHO, 2012). Di Inggris 49.936 kasus baru kanker payudara dilaporkan dan angka insidensi masih meningkat selama 2011. Meskipun tingkat kematian menurun, lebih dari 11.000 perempuan Inggris masih meninggal karena penyakit ini setiap tahun, dan ribuan korban jangka panjang menjalani terapi intensif adjuvant dan terapi adjuvant berkepanjangan yang mengikuti manajemen bedah awal tumor utama mereka (Rosen, 2006).

Penelitian menyatakan obesitas berhubungan dengan meningkatnya risiko kanker payudara pada wanita post menopause tetapi tidak terjadi pada wanita premenopouse. Hubungan antara ukuran tubuh dan prognosis kanker payudara sudah dicari dalam beberapa penelitian, terutama studi di negara barat. Peningkatan berat badan atau Body Mass Index: berat badan (kg)/ tinggi badan $(\mathrm{m})^{2}$ berhubungan dengan tingkat kelangsungan hidup. Peningkatan ukuran perut dibanding dengan ukuran pinggang berhubungan dengan mortalitas kanker payudara pada wanita post menopause (Hua Tao, 2005).

Populasi jumlah lebih besar dan studi yang mendukung gagasan hubungan obesitas adalah faktor risiko pada penderita kanker payudara post menopause. Postulat dari mekanisme biologi: Aromatisasi dari Androstenedione menjadi estradiol pada jaringan adiposa perifer dan rendahnya kadar hormone sex yang mengikat globulin (Stark, 2010).

WHO telah merekomendasikan klasifikasi IMT termasuk derajat underweight atau overweight berhubungan dengan peningkatan risiko beberapa penyakit tidak menular. Klasifikasi ini berdasarkan Indeks Massa Tubuh, yang dihitung dengan berat dalam kilogram dibagi tinggi badan dikuadratkan $\left(\mathrm{kg} / \mathrm{m}^{2}\right)$. Untuk mengukur berat relatif, IMT mudah untuk diperoleh dan dapat diterima untuk mewakili untuk menilai kekurusan dan kegemukan seseorang. Pada 1993 mengusulkan IMT batas batas $25,0-29,9$ overweight $\mathrm{kg} / \mathrm{m}^{2}$ grade $1,30,0-$ $399,9 \mathrm{~kg} / \mathrm{m}^{2}$ overweight grade $2, \geq 40,0 \mathrm{~kg} / \mathrm{m}^{2}$ overweight grade 3. Dipilih pengukuran skala obesitas karena lebih mudah dilakukan dan sudah diterima secara luas.

Diferensiasi tingkat keganasan untuk kanker payudara, menggunakan kriteria WHO yaitu system grading Nottingham (juga disebut modifikasi Elston_Ellis dari sistem grading Scarff-Bloom-Richardson). Skala penilaian ini terlibat pada 3 gambaran sel yang berbeda dan diklasifikasikan masing-masing skor dari 1-3. Klasifikasi tersebut yaitu: Grade 1 dengan skor 3-5 untuk grade rendah dengan kanker berdiferemsiasi baik (well differentiated) di mana sel kanker tidak tumbuh dengan cepat dan tidak tampak menyebar. Grade 2 dengan skor II dengan skor 6-7 untuk kanker dengan difenrensiasi jelek (moderatedly/intermediately differentiated) yang memiliki gambaran antara grade 1 dan 3 . Grade III dengan skor 8-9 untuk kanker dengan diferensiasi jelek (poorly differentiated atau undifferentiated) di mana sel kanker tumbuh dengan cepat dan lebih mungkin untuk menyebar. Manfaat dari penentuan derajat diferensiasi adalah untuk menentukan jenis terapi yang akan diberikan. Pada derajat diferensiasi jelek, di mana pertumbuhan dan penyebaran sel dianggap lebih cepat atau agresif, dibutuhkan terapi tambahan selain definitive, yaitu dengan pemberian kemoradiasi. Obesitas dapat meningkatkan mortalitas (angka kematian) seseorang dengan penyakit kronis yang mengancam jiwa seperti diabetes mellitus tipe 2, penyakit jantung dan pembuluh darah, kantung empedu, sensitivitas hormon, dan kanker payudara (Wolin, 2010). Penderita obesitas pada masa post menopause mengalami produksi estrogen dari jaringan adiposa mempunyai IGF-1 dan insulin yang merupakan faktor pertumbuhan, efek kombinasi dari perubahan ini pada menurunkan apoptosis normal dan memacu pembelahan sel dan Aromatisasi androstenedion menjadi estradiol dalam jaringan adiposa perifer dan rendahnya tingkat hormon seks pengikat globulin. 


\section{METODE}

Penelitian ini merupakan studi observasional analitik dengan desain cross sectional untuk mempelajari hubungan indeks massa tubuh dengan grading kanker payudara. Teknik pengambilan sampel pada penelitian ini adalah consecutive sampling, yaitu semua dari populasi yang datang berurutan dan memenuhi kriteria pemilihan dimasukkan dalam penelitian sampai jumlah subjek yang diperlukan terpenuhi. Sesuai "The Rule of The Thumb" besar sampel minimal adalah 30 kasus.

Tabel 1 Skoring scarff Bloom Richardson.

\begin{tabular}{lc}
\hline \multicolumn{1}{c}{ GAMBARAN } & SKOR \\
\hline Formasi tubular dan glandular & \\
$>75 \%$ & 2 \\
$10-75 \%$ & 3 \\
$>10 \%$ & \\
\hline Pleimorfik inti & 1 \\
Kecil, sel uniform reguler & 2 \\
Moderat ukuran dan variasi & 3 \\
Variasi banyak & \\
\hline Jumlah mitosis dalam LPB (400x) & 1 \\
$0-5$ & 2 \\
$6-10$ & 3 \\
\hline 11 &
\end{tabular}

Diferensiasi baik: skor 3-5

Diferensiasi sedang: skor 6-7

Diferensiasi buruk: skor 8-9

\section{HASIL DAN PEMBAHASAN}

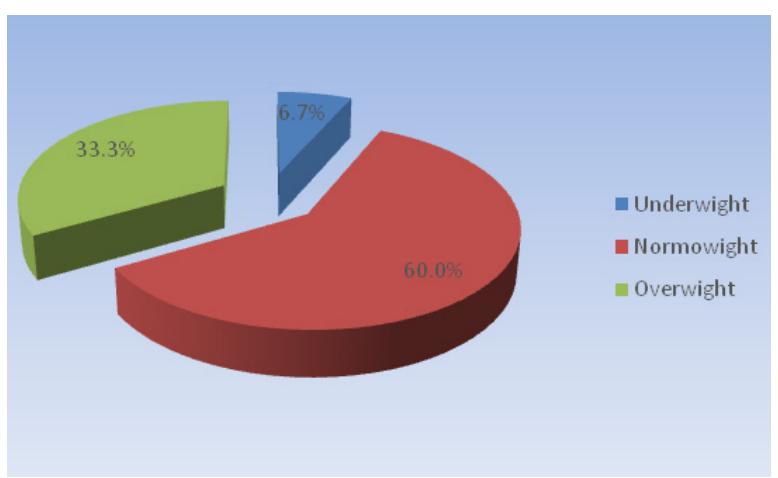

Gambar 1 Deskripsi pasien kanker payudara berdasarkan IMT

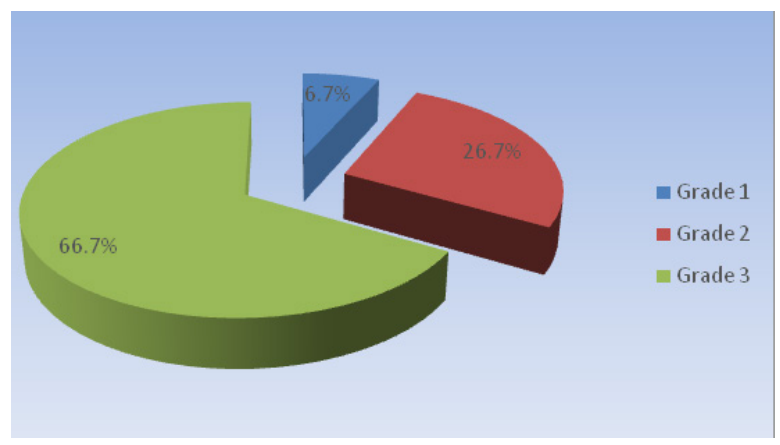

Gambar 2 Deskripsi pasien kanker payudara berdasarkan derajat diferensiasi sel

Nilai Variasi:

1) Grade: I atau Diferensiasi Baik: skor 3-5

2) Grade: II atau Diferensiasi Sedang: skor 6-7

3) Grade: III atau Diferensiasi Buruk: skor 8-9

Tabel 2 Hubungan indeks massa tubuh dengan grading pada kanker payudara

\begin{tabular}{lcccccc}
\hline \multirow{2}{*}{ IMT } & \multicolumn{9}{c}{ Grading kanker payudara } & Total & r & p \\
\cline { 2 - 4 } & Grade 1 & Grade 2 & Grade 3 & & & \\
\hline Underwight & 1 & 0 & 1 & 2 & 0,369 & 0,045 \\
& $50.0 \%$ & $0.0 \%$ & $5.0 \%$ & $6.7 \%$ & & \\
Normowight & 1 & 7 & 10 & 18 & & \\
& $50.0 \%$ & $87.5 \%$ & $50.0 \%$ & $60.0 \%$ & & \\
Overwight & 0 & 1 & 9 & 10 & \\
& $0.0 \%$ & $12.5 \%$ & $45.0 \%$ & $33.3 \%$ & & \\
Total & 2 & 8 & 20 & 30 & & \\
& $100 \%$ & $100 \%$ & $100 \%$ & $100 \%$ & & \\
\hline
\end{tabular}


Kanker payudara merupakan neoplasma ganas dimana terjadi pertumbuhan jaringan payudara abnormal yang tidak memandang jaringan sekitarnya tumbuh infiltratif dan destruktif serta dapat bermetastasis. Pada stadium yang lebih lanjut dapat menimbulkan kelainan pada kulit berupa infiltrasi, retraksi puting susu, retraksi kulit, seperti kulit jeruk (peau d'orange), benjolan-benjolan di kulit (satelit nodule) sampai dapat dijumpai ulserasi. Karsinoma duktal infiltratif merupakan group terbesar tumor ganas payudara lebih kurang 65\%-80\% dari karsinoma payudara (Burkit, 2007).

Dalam siklus normal atau sebelum gejala menopause bagi wanita, tempat primer hormon estrogen disintesis di ovarium, namun estrogen juga diproduksi dalam jaringan lemak. Setelah menopause, ketika ovarium berhenti memproduksi hormon, jaringan lemak (payudara, perut, paha, dan bokong) menjadi sumber estrogen yang paling penting, di mana tingkat estrogen pada wanita pascamenopause adalah lebih tinggi sebanyak 50 hingga 100 persen berbanding wanita berat badan normal/ideal. Biosintesis estrogen dikatalisis oleh enzim aromatase (P450 aromatase), merupakan produk dari gen CYP19. Aromatase mengkatalisis aromatisasi cincin A dari C19 androgen ke cincin aestrogen fenol $\mathrm{C} 18$. Enzim aromatase juga meningkat seiring dengan peningkatan usia dan IMT (Lorincz, 2006).

Hasil penelitian menunjukan hasil bahwa terdapat kecederungan bahwa IMT dengan kategori overwight lebih berisiko terhadap tingginya grade pada grading kanker payudara. Dalam penelitian ini didapatkan nilai koefisien korelasi sebesar 0,396 dengan nilai $\mathrm{p}=0,045$ $(p<0,05)$ yang berarti bahwa terdapat hubungan yang signifikan antara indeks massa tubuh dengan grading pada kanker payudara, dengan tingkat hubungan dalam kategori lemah.

Kesimpulan dari WCRF (2012) merupakan interpretasi dari bukti-bukti yang menggunakan indeks massa tubuh(IMT) sebagai cara pengukuran komposisi tubuh. Istilah 'body fatness' digunakan untuk menggambarkan faktor-faktor yang mendasari peningkatan risiko ini, berdasarkan data epidemiologi IMT, dan bukti mengenai mekanisme yang mendasari kelebihan adipositas dengan risiko kanker (Andreoli, 2001). Namun, IMT tidak dirancang untuk menggambarkan kegemukan tubuh, dan tidak menggambarkan komposisi tubuh karena tidak dapat membedakan lean mass dari massa lemak. Oleh karena itu, meskipun sekarang terdapat bukti signifikan bahwa IMT yang tinggi berkaitan dengan peningkatan risiko kanker payudara pada wanita pascamenopause, dan dengan hasil klinis yang lebih buruk pada semua usia, penjelasan yang tepat mendasari dari paparan masih belum jelas. Ketidakpastian ini tercermin dalam berbagai pendekatan yang berbeda yang diambil untuk mengkarakterisasi atau menggambarkan komposisi tubuh dalam literatur: IMT, berat badan, komposisi tubuh, keadaan metabolisme, dan status gizi. Kebanyakan penelitian menggunakan ukuran yang relatif sederhana dari IMT (Deurenberg, 1991). Faktor lingkungan mempengaruhi kejadian kanker payudara dan progresivitasnya. Tingginya indeks massa tubuh (IMT) dikaitkan dengan peningkatan risiko kanker payudara pascamenopause dan dengan outcome yang lebih buruk pada mereka yang memiliki riwayat kanker payudara. IMT yang tinggi umumnya diartikan sebagai kelebihan adipositas (kelebihan berat badan atau obesitas) dan WCRC menilai bahwa hubungan antara IMT dan kejadian kanker payudara dikarenakan oleh kegemukan tubuh (Deurenberg, 1991).

\section{SIMPULAN}

Ada hubungan indeks massa tubuh dengan grading pada kanker payudara, di mana ada kencederungan bahwa IMT overwight lebih berisiko terhadap tingginya grade pada grading kanker payudara.

\section{DAFTAR PUSTAKA}

Andreoli A, Borg P, Kukkonen-Harjula K, de Lorenzo A, van Marken Lichtenbelt WD,Testolin G, Vigano R, Vollaard N.2001. The Validity of Predicted Body Fat Percentage from Body Mass Index and from Impedance in Samples of Five European Populations. Diakses pada tanggal 26 Juni 2016 dari http://www.ncbi.nlm.nih.gov/pubmed/11641746

Burkitt H.G. 2007. 'Disorders of the Breast', In: 'Essential Surgery', Churchill Livingstone, New York, 539-54. 
Deurenberg P ${ }^{1}$, Weststrate JA, Seidell JC. 1991. The British of Journal Nutrition. 65 (2): 105-14. Body Mass Index as a Measure of Body Fatness: Age- and Sex-Specific Prediction Formulas. Diakses pada tanggal 26 Juni 2016 dari http://www.ncbi.nlm.nih.gov/pubmed/2043597.

Lorincz AM dan Sukumar S. 2006. Molecular links between obesity and breast cancer.

Diakses pada tanggal 26 Juni 2016 dari http://www.ncbi.nlm.nih.gov/pubmed/16728564.279-92.

Rosen P.P, 2006. 'Invasive Mammary Carcinoma', In: Harris J.R. et al: 'Diseases of the Breast', Philadelphia: Lippincot Raven, pp. 395-401.

Stark A, Stahl MS, Kirchner HL, Krum S, Prichard J, dan Evans J. 2010. Body Mass Index at the Time of Diagnosis and the Risk of Advanced Stages and Poorly Differentiated Cancers of the Breast: Findings from a Case-series Study. International Journal of Obesity 34: 1381-1386.

Tao Meng-Hua, Shu Xiao-Ou, Ruan Zhi Xian, Gao Yu-Tang, dan Zheng Wei (2005). Association of Overweight with Breast Cancer Survival. American Journal of Epidemiology

WHO. 2015. Global Database on Body Mass Index: an Interactive Surveillance Tool for Monitoring Nutrition Transition. Diakses pada tanggal 26 Juni 2016 dari http://apps.who.int/bmi/

Wolin KY, Carson K, Colditz GA. 2010. Obesity and cancer. Oncologist; 15 (6):556-565. Diakses pada tanggal 26 Juni 2016 dari

http://www.cancer.gov/aboutcancer/causesprevention/risk/obesity/obesity-fact-sheet

World Cancer Research Fund International. 2012. Weight \& cancer: Our Analysis of Global Evidence Shows that being Overweight or Obese Increases the Risk of 11 Cancers. Diakses pada tanggal 26 Juni 2016 dari www.wcrf.org/int/cancer-facts-figures/link-between-lifestyle-cancer-risk/ weight-cancer 